\title{
Lis pendens and res judicata in the Hungarian Law of Civil Procedure
}

\begin{abstract}
AdÉL KöBLÖS*
Abstract. This study aims at delineating the Hungarian rules on lis pendens and res judicata in the Code of Civil Procedure Bill when they become available in September 2016. Both institutions serve the goal to prevent inconsistent judgements in a case and therefore to establish legal certainty, nevertheless certain exceptions are regulated. Res judicata and lis pendens are formal barriers to re-litigation, the judge takes them into account ex officio. Under the present and future rules there is a rather wide opportunity to deteriorate finality with legal recourses available against final judgments.
\end{abstract}

Keywords: res judicata, lis pendens, legal certainty

\section{INTRODUCTION}

This study aims at delineating the Hungarian rules on lis pendens and res judicata in the Code of Civil Procedure Bill (hereafter, the new Code) when they become available in September 2016. ${ }^{1}$ It is worth briefly discussing the old rules in order to understand the present ones and to see how the new Code is planning to change the provisions currently in effect. For this reason, the majority of references will be made to the code of $1911^{2}$ and sometimes to the act of $1868^{3}$ which were directly or indirectly influenced by the Austrian and German law. Even though the code of civil procedure of 1952 (that is in effect now) was passed in the communist era and bore the strong impact of the soviet ideas, it was amended several times in order to restore the role of the traditional principles of civil litigation after the change of the regime in 1989 and to catch up with the latest trends and the challenges of recent developments. The recent thinking about res judicata and lis pendens cannot be aptly demonstrated without reference not only to the historical background but also to a wider, especially constitutional context of these legal institutions and to the case law of the courts.

It is generally known that both institutions serve the goal to prevent inconsistent judgements in a case and therefore to establish legal certainty and it is also accepted that there are conflicting interests (such as procedural fairness or the quest of material truth, etc.) that require a proper balance between different objectives and regulate exceptions. Both legal institutions save sources of the courts, the parties and also the whole society and can prevent vexatious litigations. However, it is also very important not to deprive the parties from their right to access to justice where a dispute or a segment of a dispute has not been tried yet or the prior procedure did not meet the essential requirements of civil justice. The proper balance might vary in time and in accordance with cultural conditions and different expectations.

* Senior research fellow at the National University of Public Service. E-mail: koblos@mkab.hu

1 The Bill is available: http://www.parlament.hu/irom40/11900/11900.pdf accessed 30 September 2016.

2 Act I of 1911 on the code of civil procedure.

3 Act LIV of 1868 on civil procedure. 


\section{CONSTITUTIONAL BACKGROUND}

The Constitutional Court of Hungary declared in one of its early (1992) decisions ${ }^{4}$ that res judicata stemmed from the rule of law principle as it was one of the way how legal certainty was secured. "The requirements of substantive justice and legal certainty are brought into harmony by the institution of legal validity - once more on the basis of the priority of legal certainty.' In this judgment, the Court was dealing with the legal institution of 'protest of illegality' both in criminal and civil procedures and found it unconstitutional as it violated legal certainty , human dignity and the right to a fair hearing. The formal aspect of finality was brought into focus, similarly to several judgments of the European Court of Human Rights (ECHR).

Res judicata is also part of the fundamental right to a fair trial. The European Court of Human Rights explained the relation between res judicata and this fundamental right as '[...] the Court reiterates that the right to a fair hearing before a tribunal as guaranteed by Article $6 \S 1$ of the Convention must be interpreted in the light of the Preamble to the Convention, which, in its relevant part, declares the rule of law to be part of the common heritage of the Contracting States'. One of the fundamental aspects of the rule of law is the principle of legal certainty, which requires, among other things, that where the courts have finally determined an issue, their ruling should not be called into question (see Brumărescu, cited above, § 61).

Legal certainty presupposes respect for the principle of res judicata (ibid., § 62), that is the principle of the finality of judgments. This principle underlines that no party is entitled to seek a review of a final and binding judgment merely for the purpose of obtaining a rehearing and a fresh determination of the case. Higher courts' power of review should be exercised to correct judicial errors and miscarriages of justice but not to carry out a fresh examination. The review should not be treated as an appeal in disguise and the mere possibility of there being two views on the subject is not a ground for re-examination. A departure from that principle is only justified when made necessary by circumstances of a substantial and compelling character.' (Ryabykh v Russia, 52854/99, 24 July 2003, §§ 5152]

In the Ryabykh case, the ECHR found a judgment rendered in a supervisory review procedure contrary to Article $6 \S 1$ of the Convention. The application for a supervisory review was lodged by the president of a regional court, nine months after the judgment had become final and the judgment was overturned on the ground that the district court judge had misinterpreted relevant laws. This legal institution shows many similarities to the protest of illegality.

The interpretation of the right to a fair hearing in relation with res judicata as quoted above is now part of the case law of the Hungarian Constitutional Court. ${ }^{5}$

\section{LIS PENDENS AND RES JUDICATA AS FORMAL BARRIERS TO RE-LITIGATION}

In the code of 1911, lis pendens was already a formal barrier to a civil lawsuit on the ground of which the court on its own initiative had to reject the statement of claim without issuing summons. ${ }^{6}$ Another (prior) procedure pending before a court excluded the adjudication of a

4 Decision 9 of 1992, 30 January 1992.

5 Decision 30 of 2014, 30 September 2014, Reasoning [78].

${ }^{6}$ Section 141 (1), Section 147 and 180 of Act I of 1911. 
case on the merits. ${ }^{7}$ Res judicata, however, was not an exceptio litis ingressum imediens, so the court rendered a new judgment dismissing a new claim. Even though seemingly it was a decision on the merits, in essence, it did not concern the legal relationship adjudicated in the prior judgment. ${ }^{8}$ The res judicata effect of a judgment had to be taken into account by the court on its own motion..$^{9}$ This provision in the code of 1911 was a new one, for the Act LIV of 1868 did not contain such an express rule, nevertheless in practice a prior final judgment in the same case was deemed a fact which the court was aware of ex officio and the judge took it into account on their own initiative. ${ }^{10}$

The code of 1952 deviated from this solution and regulated res judicata as a formal bar. Thus a final judgment in the same case led to the rejection of the statement of claim similarly to lis pendens ${ }^{11}$ and this rule is still in effect. If the court perceives lis pendens or res judicata once the summons has been issued, it terminates the procedure on its own initiative. The defendant may also base their (formal) defence on these bars. On appeal, the court terminates the procedure and sets aside the first instance judgment. If two final judgments have been rendered in the same case, the subsequent judgment can be challenged in an application for renewal. ${ }^{12}$ In Hungary, res judicata and lis pendens are mainly rooted in public policy, for both bars to the litigation must be taken into account by the court on its own initiative. There is one exception to this rule - once the second judgment is final, an application is needed to quash it in a re-opening procedure.

It seems that the new Code will uphold this system, though it will reword the current text concerning rejection of the statement of claim ${ }^{13}$ without giving reasons why it is necessary. ${ }^{14}$ It might mean that there is no substantive alteration from the present rules, the reformulation might serve stylistic or other similar objectives. ${ }^{15}$

\section{LIS PENDENS}

The lis pendens rule has little practical significance in Hungary as the law (both procedural and substantive) is the same in the whole country. Even though the case law of the different courts might vary to some extent, finally cases or at least the divergent case law might end up before the Curia as supreme court which is responsible for unifying the case law. ${ }^{16}$ Therefore forum shopping is basically unknown in domestic context. It has much more significance in cross, border litigations. In this aspect, the EU regulations and the Lugano regime, other multilateral or bilateral international agreements and the act on conflict of laws ${ }^{17}$ have relevance. If there is a lawsuit pending before a foreign court, the Hungarian

7 Magyary and Nizsalovszky (1939) 331.

8 Magyary and Nizsalovszky 474.

9 Section 411 (2) of Act I of 1911.

10 Magyary (1898) 265.

11 Section 130 (1) point d) of Act III of 1952.

12 See Section 157 point a), Section 252 (1), Section 260 (1) point c) of Act III of 1952.

13 Section 176 (1) point d) of the new Code.

14 Section 240 (1) point a), Section 379, Section 392 point d) of the new Code.

15 Even though the new text, as far as I see, is less clear than the one in force.

16 Article 25 (3), Fundamental Law.

17 Law-decree 13 of 1979, the conception of a new act on conflict of laws was published in September 2016, the act was passed in 2017 (Act XXVIII of 2017), it will be come into force on 1 January 2018. 
court rejects the statement of claim or terminates the procedure provided that the foreign judgment is recognisable and enforceable under the Hungarian act on conflict of laws ${ }^{18}$.

Under the code of 1952 a lawsuit is deemed to be pending when the court notifies the statement of claim to the defendant ${ }^{19}$, meaning that the statement of claim is served on the defendant. ${ }^{20}$ This system was already known in the code of 1911 and will be maintained in the new Code. Under the Hungarian law, the court is responsible for the notification of the proceedings to the defendant. In a vast majority of the cases the statement of claim is mailed to the defendant.

The time of service is quite uncertain. On the one hand, the workload of the courts or other circumstances e.g., need for completion or to transfer the case to the competent court might have influence thereon. On the other hand, the defendant might play tricks to avoid the proper service of the proceedings. This weakens the positions of the claimant especially in international cases, where the Brussels or Lugano regimes or international agreements are not applicable. If the defendant refuses or culpably fails to take over court documents, a legal fiction ${ }^{21}$ helps the claimant, provided that the service is to be carried out in Hungary. The new Code plans to broaden the possibility of the service by a court bailiff to the case where a statement of claim is to be served on the defendant in Hungary. ${ }^{22}$

A lawsuit pending before the same or another court bars a new litigation only if the parties, the facts and the claim (rights asserted) are the same in the prior and the subsequent litigation. For example, the later lawsuit may not be terminated (the statement may not be rejected) when two different persons (one of them having a private interest, the other is authorized by the law) have instituted two different procedures against the same defendants (parties to a contract) in order to declare the same contract null and void on the same grounds (contra bonos mores). ${ }^{23}$ The identity of facts, rights and parties is determined similarly to res judicata as the scope of these two institutions is almost the same. However, to some extent, the exception of lis pendens is narrower than res judicata i.e., lis pendens does not affect persons not parties to the previous lawsuit while res judicata might. ${ }^{24}$

Under the rules in effect, offsetting is basically an institution of the substantive law even though the code of civil procedure of 1952 also contains some provisions concerning offsets, mainly submission deadlines and a rule in relation with res judicata. It is generally accepted in case law that the plea of set-off does not result in a pending procedure. Thus, a defence based on the fact that the defendant set off their claim against the debt (the claimant's claim) does not prevent them from instituting a separate lawsuit as a claimant for

18 Section 56 of Law-decree 13 of 1979.

19 Section 128 of Act III of 1952.

20 Section 129 of Act III of 1952 provides that a copy of the statement of claim shall be attached to the court order transferring the case to the competent court. In the case law the service of the statement of claim together with the transferring order is considered as a notification and the procedure is deemed pending. (BH 2003. 37) There is another theory in accordance to which a statement of claim may be notified to the defendant only if it is capable of being tried and a hearing can be appointed. Any service of the statement claim on the defendant before this conclusion may not result in a procedure pending.

${ }^{21}$ It is called presumption in Act III of 1952 [see Section 99 (2)], in the new Code will be a legal fiction [see Section 137 (2)].

22 Section 141 of the new Code.

23 BH 2004. 476.

24 Magyary and Nizsalovszky (1939) 474. 
the same claim. ${ }^{25}$ The new Code pursues a significantly different conception. Offsetting is planned to be a substantive law institution and also a new procedural means of defence. It will be more like a counterclaim, with similar formalities and legal effects. Therefore the submission of a set-off will have the same legal effects as filing a statement of claim and the notification of the claimant of the set-off will entail lis pendens. ${ }^{26}$ This modification is limited to offsets and does not affect other pleas of substantive law e.g., plea of guarantee, limitation.

\section{RES JUDICATA}

Originally the parties' will and initiative led to the formal regulation of res judicata by the state. ${ }^{27}$ Nowadays, it is treated as part of procedural rather than civil law ${ }^{28}$ as it flows from legal certainty and serves public interest. ${ }^{29}$ There have been several theories on the concept, character, effects and scope of res judicata etc. The various German, French, Austrian doctrines are reflected in the Hungarian jurisprudence. ${ }^{30}$ The diversity of views and resulting difficulties and critics means that this study can only briefly present the latest mainstream theory.

Under the Hungarian law, there is a distinction between 'formal' and 'substantive' (aspects of) finality. Certain scholars, following Farkas ${ }^{31}$, believe that these two aspects together constitute res judicata. ${ }^{32}$ Formal finality is a feature of judicial decisions while substantive finality is the effect deriving from this feature. In other monographs formal and substantive finality is treated much more separately. ${ }^{33}$ Magyary's doctrine was dominant in the previous jurisprudence. He argued that the distinction between formal and substantive finality was false and finality was one kind and equalled to the fact that a judgment is no longer subject to appeal. 'Substantive finality' was only the consequence of finality. ${ }^{34}$

The distinction between formal and substantive finality had been already analysed in previous commentaries and monographs, but the code of civil procedure of 1911 did not use these terminologies. In the code of 1952 Sections 229 and 230 expressly mention substantive finality ('anyagi jogerö') while 'finality' ('jogerö') is used in the formal sense.

25 BDT 2003. 806. The old case law was not entirely homogeneous: one can find authorities accepting this interpretation: Kovács (1927.) 477-78, 481-82, while others were of the opinion that the submission of a set-off is capable of establishing lis pendens: Antalfi (1915.) 400.

26 Section 209 (9) and 210 of the new Code, Reasoning 340-42.

27 Zita Pákozdi cites Habermann's work: (1935) 3., in her PhD dissertation (http://doktori. bibl.u-szeged.hu/2743/1/Pakozdi_Zita_ertekezes.pdf accessed 6 June 2017.

28 At the beginning of the 19th century there were still upholders of the theory that res judicata, especially its substantive aspect belongs to civil law (too). See: Magyary and Nizsalovszky (1939) 471; Herczegh (1901) 416. Farkas verifies in his monograph why res judicata forms part of the law of civil procedure and emphasises the practical consequences of this classification. Farkas (1976) 41-43.

29 The very strong impact of public policy on res judicata effect involves that arbitration awards infringing res judicata are overturned as being in conflict with the rules of Hungarian public policy. See BH 2015. 14.

30 See e.g.: Herczeg (1901) 416-18; Magyary and Nizsalovszky (1939) 469-85; Farkas (1976) 28-35, 41-43.

31 Farkas (1976) 23.

32 Szabó (2013) 319-20; Kengyel (2012) 358.

33 Wopera (2008) 427, 430-33.

34 Magyary (1898) 262. 
The new Code will preserve this differentiation. The subtitle 'finality' ('jogerö') will deal with the formal aspect of finality ${ }^{35}$ while res judicata effect ('anyagi jogeröhatás') is regulated under a separate subtitle.

\subsection{Formal aspect of res judicata}

Formal finality is an attribute in a judicial decision that it cannot be challenged before the courts. This quality can be relative or absolute. ${ }^{36}$ A judgment is relatively final when certain remedies are already excluded, however others are still available. Absolute finality means that a judgment cannot be challenged with any kind of legal recourse. From relative to absolute finality there might be several stages and from stage to stage there are fewer and fewer remedies available. The order of the individual stages follows the elapsing of the time limits within which a remedy may be filed.

Under the code of civil procedure of 1911, formal finality meant that the judgment was not subject to further appeal. ${ }^{37}$ Appeal against a first instance judgment to the court of second instance ('fellebbezés') and review appeal (as to its essence it was a revision in law) against a second instance judgment to the Curia or to a regional court of appeal ('itélötábla') qualified as appeals ('fellebbvitel'). These were (ordinary) remedies available within the normal procedural regime for review of a lower court judgment by appeal to a higher court. ${ }^{38}$ The rule also referred to statement of objection ('ellentmondás') against default judgments. However it was not an appellate remedy because the case did not get before a higher court but it was tried before the original first instance court. Re-opening was an extraordinary legal recourse against final judgments. An action for re-opening usually could be submitted within five years of finality. ${ }^{39}$ Some grounds for re-opening, however, could be raised irrespective of this five years time limit. ${ }^{40}$ Further legal recourses might also render opportunity for the parties to make the court set aside or modify a final judgment, such as a justification of omission or an application for correction or supplement.

The system of remedies was restructured in the code of 1952. A special opportunity was opened for the public prosecutor to challenge judicial decisions in order to secure legality. Later on, the protest of illegality was introduced instead. This institution was annulled by the Constitutional Court in 1992, as mentioned. After the ruling of the Constitutional Court, the legislator restored the appeal review as a remedy available against final judgments. The overall essence has not changed despite several modifications of the particular rules. It is an appeal to the Curia in questions of law - a revision in law.

Under the rules in effect review appeal, re-opening and constitutional complaint are available against a final judgment. It is also possible to request the court to correct or supplement a final judgment. A successful justification of the omission of the last hearing may also lead to the quashing of a final judgment. The finality of a judgment might be

35 Section 367.

36 Kengyel (2012) 358.

37 Section 410.

38 Söderlund (2005) 301.

39 It was an objective deadline. A subjective deadline of 6 months was also applied. See: Section 567.

40 E.g. the party lacked capacity to act in the procedure but conducted the litigation in person, a third party acted on behalf of a party without authorisation, a party - concealing the real data - sued the opponent as if his or her residence were unknown. In the case of these grounds for re-opening the subjective time limit was also applicable. 
broken through in other ways, as well e.g., when the first instance judgment is appealed only in part, hence the rest becomes final but the appeal court overturns the complete judgment because of a very serious procedural mistake ${ }^{41}$ or when the court has handed down a part judgment and it is necessary to modify it as a result of the adjudication of the rest of the case (offsetting or counterclaim). ${ }^{42}$ It is also possible to institute a new action if the defendant is ordered to perform an obligation maturing in the future and the circumstances that formed the basis of the judgment, subsequently significantly change. ${ }^{43}$ These exceptions to res judicata effect will also be saved in the new Code. ${ }^{44}$

The grounds for re-opening are precisely set out in the code of 1952 and are restricted to serious errors, such as a prior final judgment in the same case (res judicata); a criminal offence committed by the judge or someone else or an irregular service by publication. A reopening can be also based on new facts or evidence which are the most frequently raised grounds. ${ }^{45}$ A successful constitutional complaint against the legal provision applied in a final judgment may be also a cause of re-opening. ${ }^{46}$ These grounds will be supplemented in the new Code with an extra cause - a judgment of the European Court of Human Rights stating the violation of a fundamental right. ${ }^{47}$ The deadline for filing a petition for reopening will not change.

Review appeal (revision in law) is a much broader remedy against final judgments (and certain court orders) than re-opening. Any kind of violation of the law may constitute a cause for review appeal, notwithstanding whether a judgment is contrary to substantive or procedural law to a certain extent, as it is elaborated in the case law of the Curia and the predecessor Supreme Court. ${ }^{48}$ The facts laid down in the final judgment are revisable. The Curia is vested with the exclusive jurisdiction over review appeal - one of the most important means of unifying the case law. The code of 1952 provides for several exceptions to review appeal in order not to overload the supreme forum. The regulation is quite complex e.g., there are exceptions to the exceptions and it depends on various factors, including the sum disputed in a petition for review appeal; the subject matter of the case or whether the appellate court approved the first instance judgment. These rules open a very broad way to dissolve res judicata but only a relatively small proportion of cases gets before the Curia mainly due to cost. The deadline for submission is usually 60 days. ${ }^{49}$

The new Code will not revert the review appeal to ordinary remedy, as in the code of 1911. It remains a legal recourse against final judgments. A leave to appeal system will be introduced in pecuniary cases, provided that the sum in dispute does not exceed HUF 5

41 Section 252 (1) and (2) of Act III of 1952.

42 Section 213 (2) of Act III of 1952.

43 Section 230 of Act III of 1952.

44 Section 370 (2), Section 341 (2), Section 361.

45 Section 260 of Act III of 1952.

46 Section 262/A of Act III of 1952.

47 Section 392 point c). A previous draft of the new Code (published in April 2016) contained a reference to the judgments of the European Court of Justice as a ground for re-opening. This reference nevertheless was deleted from the text and the reasoning in the version published in June does not give any explanation for the disappearance, even though the prior reasoning was dealing with this issue in great details.

48 BH1999. 44.

49 Section 272 (1) of the Act III of 1952. The omission of this time limit can be justified under the general rules, so there is a 15 day subjective and a 3 month time limit. 
millions. ${ }^{50}$ Permission will be granted where it serves the uniform interpretation or the development of the case law, where it is necessary to make a reference to the European Court of Justice or where the social or legal significance of the question(s) raised justifies the leave to appeal. The deadline for petition will be shortened to 45 days. ${ }^{51}$

Constitutional complaints can result in setting aside a final judgment in two ways. One is when a legal provision applied in (handing down) a final judgment is annulled by the Constitutional Court. If a rule of substantive law is found unconstitutional, the party may submit a petition for re-opening and in the repeated litigation the annulled rule may not be applied. If a procedural provision is annulled, the Curia decides how the violation of the right shall be remedied. It might involve that the final judgment is overturned. The other way is when the final judgment itself, the interpretation of a legal provision, is contested before the Constitutional Court. In this latter case, the Constitutional Court is authorised to annul the final judgment that violates a constitutional right. ${ }^{52}$ A constitutional complaint can be filed within 60 days. ${ }^{53}$ The new Code does not plan any modification in this respect. ${ }^{54}$

In comparison with the old rules, it can be seen that there are new challenges that res iudicata have to face with and finality is subordinated to certain higher objectives (remedying the violation of constitutional and fundamental rights) and finality is most frequently deteriorated in a review appeal procedure. This legal recourse could be regulated as having a delaying effect on finality. In this case, the reform of enforceability should be contemplated, since currently enforceability with some exceptions is bound to finality.

One of the main practical issues of the formal aspect of finality is the time when a judgment becomes binding. It depends on whether a decision is subject to appeal and, if so, whether the parties waive their right or simply do not appeal the decision or withdraw the appeal already lodged. This is regulated in the code of civil procedure in details. ${ }^{55}$ The date when a judgment becomes final is officially verified by the court. ${ }^{56}$

\subsection{Res judicata effect}

Res judicata effect can be defined from a positive and a negative aspect. In the positive sense, it means that the parties, courts and other authorities are bound by the judgment and the ruling therein is normative for them. The negative aspect precludes continued or repeated litigation of the case between the same parties (exception rei iudicatae). ${ }^{57}$ The Hungarian civil procedural law does not distinguish between claim preclusion and issue preclusion. Traditionally res judicata has a narrow scope, similarly to other continental law systems but the new Code will broaden the res judicata effect to some extent.

Basically judgments, including default judgments (bírósági meghagyás), part judgments and interim judgments and orders for payment are capable of having res iudicata

${ }^{50}$ It is cc. EUR 1600-1700.

51 Section 412 (1) of the new Code. Justification of the omission can be filed within 15 days.

52 Section 361 of the Act III of 1952.

53 The omission of this deadline can be justified but no Constitutional Court proceedings may be initiated 180 days after the communication of the decision.

54 Section 427 (2) of the new Code.

55 Section 228 of Act III of 1952, Section 358 of the new Code.

56 Section 230/A of Act III of 1952, Section 359 of the new Code.

57 Kengyel (2012) 360; Szabó (2013) 323. 
effect. Settlements ${ }^{58}$ approved by the court ${ }^{59}$ and certain orders issued in a winding-up procedure $^{60}$ also have res judicata effect

Res judicata bars litigation only if the parties, the facts and the right asserted (the subject matter of the lawsuit) are identical in the prior and the subsequent action. In theory this seems a quite simple rule; in practice it raises several difficulties.

The subjects affected by the res judicata effect were and are not exhaustively listed in the codes of civil procedure. It was explained in the preparatory reports of and the reasons for the code of $1911^{61}$ that this issue is more deeply rooted in civil law rules than it could be regulated in the code of civil procedure. ${ }^{62}$ Final judgments certainly bind the parties to a lawsuit (inter partes effect) and their universal successors or assignees. ${ }^{63}$ A person in favour of whom the public prosecutor or another person or organisation authorised by the law instituted a legal action is also bound by the final judgment provided that it was served on them and it became final against this person. ${ }^{64}$

Civil law rules may provide that a final judgment binds even other persons not parties to an action e.g., insurance cases ${ }^{65}$, or when a lawsuit has been filed concerning a real estate is registered in the land records, res judicata effect extends to anyone who obtains rights in the land afterwards ${ }^{66}$ ). These persons - provided that they are not parties - may participate in the lawsuit as (independent) interferers. ${ }^{67}$ There might be other situations where someone sues a defendant in their own name but vindicating a third person's right. In such cases final judgment also binds this third person. ${ }^{68}$

There are judgments which have erga or contra omnes effect. In the case law of the Curia res judicata effect is distinguished from contra omnes effect. ${ }^{69}$ Erga contra effect

58 Court orders approving settlements are subject to appeal but no review appeal (Sections of Act III of 1952). A settlement approved by the court can be contested on substantive law grounds, thus either of the parties can institute a separate action in order to declare the agreement invalid. If a contract is null and void anyone bearing a legal interest can raise it at any time, there is no deadline for that, however the general rules on limitation are applicable if a party seeks further legal consequences and compensation. Otherwise the avoidance of a contract can be contested within one year of the day when the parties made the contract. (See: Sections 6:88 and 6:89 of Act V of 2013).

59 Certain orders of notaries public also have res judicata effect, i.e. the order approving a settlement in an inheritance case. [Section 12 (1) of Act XXXVIII of 2010].

60 BH 2004. 291, BH 2010. 335.

${ }^{61}$ See e.g. Antalfi (1915) 715.

62 Magyary and Nizsalovszky (1939) 483.

${ }^{63}$ Section 229 (1) of Act III of 1952, Section 360 (1) of the new Code.

${ }^{64}$ Section 229 (2) of Act III of 1952, Section 360 (2) of the new Code. There are scholars who believed that this provision was superfluous and the condition of service is confusing, since under another provision [Section 49 (4)] of the Code of Civil Procedure of 1952 these persons are parties to the lawsuit ex lege. See also PK 196 on the interpretation of Section 229 (2). It rules that where the first instance judgment has not been served on the person affected, the res judicata effect does not prevent this person from re-litigation. However, if the person affected was not notified of the proceedings but the first instance judgment was properly served on him or her and he or she files an appeal, the judgment might be set aside on ground of Section 252 (2) of the Act III of 1952.

65 Section 32 (2) of Act LXII of 2009 on mandatory automobile-insurance.

66 Kengyel (2012) 137-38, BDT2013. 2868.

${ }^{67}$ See Section 57 (1) of Act III 1952 and Section 44 (5) of the new Code.

68 See Kengyel (2012) 361.

69 Civil law ruling Nr. 14/2012. 
derives from the substantive law rules. A judgment delivered in certain status actions (matrimonial actions ${ }^{70}$, affiliation and parenthood ${ }^{71}$, dissolution of adoption ${ }^{72}$, or actions concerning parental responsibility ${ }^{73}$ and guardianship ${ }^{74}$ ) has erga omnes effect. In case law judgments handed down in actions relating to in rem rights in real property or other things registered in public records have contra omnes effect.

The new code of civil procedure will introduce a particular procedure on collective litigation. There will be two types of collective proceedings: public interest litigation and opt-in class actions. Regarding collective actions, the new code will contain detailed additional rules on res judicata effect. A judgment handed down in public interest litigation binds the particular obligees if certain conditions are met. The defendant shall notify, in writing, each obligee of the final judgment within thirty days. The defendant shall also inform the obligees that the res judicata effect of the judgment covers them unless the obligee notifies the defendant in writing within sixty days that they vindicate the individual right to institute a separate lawsuit. If the defendant fails to notify an obligee, it is deemed as if they vindicated the right to sue. Thus, if the defendant properly notifies and informs the obligee but the latter does not maintain the right to sue individually the defendant, the obligee is covered by the res judicata effect. $^{75}$

Currently the procedural rules of different kinds of public interest litigation are not included in the code of civil procedure. However some relevant provisions might be found in particular acts. e.g. in Section 6:105 (2) of the Civil Code provides that in public-interest proceedings in connection with unfair standard contract terms, the court shall establish the annulment of an unfair contract term in favour of all of the parties with which the party imposing the condition has a contractual relationship.

The most difficult issue of the res judicata effect is how to define the identity of the facts and the claims (rights) in the prior and the subsequent proceedings - what is the scope of the res judicata effect. In Hungary, res judicata is applied with a narrow scope as a bar of re-litigation, therefore, it might occur that courts hand down contradicting final judgments. ${ }^{76}$

There was a debate whether only the disposing part of a judgment or also the reasoning had the res judicata effect. ${ }^{77}$ It is now generally accepted that the decision on the merits is relevant irrespective in which part of a judgment it can be found. In accordance with the generally accepted theory, the ruling on the claim entails res judicata effect and this decision is to be made out the entire content of the judgment. ${ }^{78}$ When a claim is dismissed, the reasoning contains relevant elements of the decision as the disposing part limited to the dismissal of the claim without further particularities. ${ }^{79}$ The doctrine mentioned above is reflected in the case law. In a judgment published in 2002, the Supreme Court pointed out that the res judicata effect extends to the ruling on the claim and also to the relevant facts

70 Section 4:6 (3), Section 4:14 (2), Section 4:23 (4) of Act V of 2013.

71 Section 4:103 (4), Section 4:112 (4), Section 4:118 (6) of Act V of 2013.

72 Section 4:140 (3) of Act V of 2013.

73 Section 4:193 (4) of Act V of 2013.

74 Section 311 (1) of Act III of 1952.

75 Section 578 of the new Code.

76 See Magyary (1898) 276-77, Farkas (1976) 74-75.

77 See Magyary's comments on Savigny's theory: Magyary (1898) 277.

78 Farkas cites Schönvitzky's theory: Farkas (1976) 75.

79 See the explanation for Sections 410 and 411 of the Act I of 1911 [e.g. in: Antalfi (1915) 715]. 
and legal arguments that form the basis of this ruling. ${ }^{80}$ Thus, the legal qualification or classification of a legal relationship between the parties, as part of the legal argumentation, binds the courts in further lawsuits deriving from the same relationship. ${ }^{81}$ In the given case and in the prior litigation, the court stated that termination of the civil law contract between the parties was invalid. In a subsequent litigation, the trial court on appeal stated that the same contract was void and null. In the review appeal procedure, the Supreme Court emphasised that once a court handed down a final judgment stating the termination of a civil law contract invalid, it also implied that the court qualified the parties' contract as an existing and valid civil law agreement as the court could not rule on the invalidity of the termination of a non-existing or null and void contract. This explanation resonates to Magyary's interpretation of the res judicata effect who was of the opinion that res judicata prevented the prior defendant, who was ordered by a final judgment to perform an obligation, from further contesting the existence (it did not come into existence or ceased to exist) of the right on the basis of which the prior final decision was delivered. Those challenges were raised or could have been put forward in the previous proceeding. In the first case, the court actually ruled on those challenges while in the latter case it would not be expedient to demolish the effect of the previous final judgment. ${ }^{82}$ Nevertheless, if the court has to consider another legal relationship as a precondition of the claim before it, the res judicata effect does not extend to those deliberations. ${ }^{83}$

This understanding of res judicata is not without criticism. Some commentators are of the opinion that res judicata does not extend at all to preconditions deliberated in the reasoning. Hence, the existence of a legal relationship can be successfully challenged in a subsequent lawsuit if the prior judgment, within the boundaries of the parties' claims, ruled only on the performance of on obligation deriving from this legal relationship. ${ }^{84}$

In a judgment published in 1988, the Supreme Court gave a finer interpretation to which part of the reasoning entailed the res judicata effect. In accordance with this specification res judicata extends to the facts that constitute the indispensable basis of the ruling in the disposing part of the final judgment. Other facts may be contested in a further litigation. In the case before the Supreme Court, there was a dispute concerning dissolution of a matrimonial property regime. In the reasoning of a prior final judgment relating to divorce, the court stated the time when the spouses separated. Only the fact but not the time of separation had relevance in relation with the divorce. Hence, in the subsequent litigation, the parties could successfully challenge the statements as to the time of separation included in the prior judgment. ${ }^{85}$ This approach will be changed in the new Code as if divorce precedes or runs in line with a litigation relating to rights arising out a matrimonial relationship, the court of divorce shall state the duration of the spouses' life as a couple and this ruling will be normative in the lawsuit concerning property rights. ${ }^{86}$

80 See also BH 1994.491.

81 BH 2002.235.

82 Magyary (1898) 268-69, See: EBH 2002.642.

83 Magyary (1898) 275-77.

${ }^{84}$ Kovács (1928) 855. It is worth mentioning that the author cites the contradicting views of different scholars, including Magyary's. See on page 856. Pákozdi shares the view of narrow concept of res judicata effect [Pákozdi (2015) II.2.2.1.]

85 BH 1988. 358.

86 Section 463 of the new Code. 
Identification of the two elements mentioned above i.e. claim and facts of the two actions goes in the very heart of civil procedures: what does a judge have to adjudicate, how much are they bound to the parties pleadings and how far they can go in taking account circumstances (facts, evidence, legal arguments) on their initiative ${ }^{87}$ Deliberating this issue is not the subject of the present study, it is necessary to mention at least that in this regard, the new Code will bring a decisive change by placing more responsibility on the parties than before, provided that they have legal representatives. ${ }^{88}$ Today, not without exceptions, the alleged facts and the prayer for relief determines the boundaries of the contest, irrespective of the legal arguments of the parties. ${ }^{89}$ The new Code will lay heavier emphasis on the legal contentions ${ }^{90}$.

Schönvitzky pointed out that real difficulties typically arise in identifying the claim i.e. the right asserted in the two procedures. ${ }^{91}$ As previously mentioned, the claim is currently identified on the basis of the facts presented and the prayer for relief. Taking facts, it is said that several rights may derive from them e.g., guarantee and damages, therefore res judicata may not preclude several litigations based on different rights. The prayer for relief helps to decide whether the claims are identical in the two procedures or not. ${ }^{92}$ It is important to see, however, that an individual fact may be relevant in relation with one right but irrelevant in relation with another.

Under the system adopted in the new Code, as far as a party has a legal representative, the claim shall be identified by reference to substantive law rules. ${ }^{93}$ In those cases the identity of the claims will be easily determined. Where the claimant does not have a legal representative, the difficulty, which the courts face today will remain in my opinion.

In a previous draft of the new Code, the res judicata effect was planned to be extended to the case where the claimant failed to plead all the relevant facts in the prior procedure and intended to institute a subsequent litigation pursuing the same claim but supplementing the factual basis. The party would have been prevented from commencing a new litigation on the basis of the same right. This part of the provision was finally deleted. ${ }^{94}$

87 On this topic see: Pákozdi (2016).

${ }^{88}$ In procedures before the courts of justice legal representation will be mandatory, while in lawsuits before the district courts as a rule the parties can have legal representatives. Section 72 of the new Code.

89 The court - in accordance with the principle of iura novit curia and da mihi factum, dabi tibi ius - qualifies or re-qualifies the facts presented (and proved) and adjudicates the case in favour of the claimant even if the facts proved underpin another substantive right than the one pleaded by reference to a particular legal provision. (See BH 2004. 504, EBH 2006. 1422) Under this regime facts have much more significance in identifying the claim than legal argumentation. (See BH 2001. 22) This system in today's jurisprudence is based on the concept that the subject matter of the dispute has two elements: facts and prayer for relief. [On this issue see: Éless and Döme (2014) 50-78; Éless and Parlagi (2014) 355-61, Pákozdi (2014) 328-54.].

90 See 170 (2) point b) of the new Code.

91 Schönvitzky,(1938) 236.

92 Farkas (1976) 79-82.

93 It will be a necessary element of a statement claim to allege a right (the claim) by reference to the substantive law rule that determines the facts directly establishing a subjective right and that entitles to make a claim. Section 170 (2) point b), Section 7 (1) point 7 of the new Code.

94 See Section 360 (1) in the draft of the new Code as it was published in June 2016. http:// www.kormany.hu/hu/dok?page=3\&source=5\&type=302\#! DocumentBrowse accessed 6 June 2017. 
A significantly new solution can be found in the new Code concerning offsets. Under the present provisions res judicata effect extends to a set-off of the adversary, put forward not in a form of counterclaim but as a defence, a substantive law excuse ${ }^{95}$, only if the court entertained it. ${ }^{96}$ If the court finds the set-off unfounded or that the conditions of the offsetting are not met, it does not entail res judicata effect. As offsetting is not a separate claim in the litigation (contrary to counterclaims), the disposing part of the judgment does not contain any ruling thereon. Whether the court entertained or dismissed the set-off, it can be made out from the reasoning. The new Code will extend res judicata effect to the adversary's claim even where the court finds the set-off baseless, the ruling thereon will appear in the disposing part. However, the adversary will not be prevented from instituting a new lawsuit if the set-off is dismissed on the ground that the preconditions of offsetting are not satisfied. ${ }^{97}$ The deviation from the present rules on res judicata effect concerning set-off reflects the new approach of set-off in the new Code, as it will get closer to a counterclaim. ${ }^{98}$

\section{CONCLUSIONS}

In Hungary, lis pendens and res judicata have a strong relation with constitutional requirements such as legal certainty and a right to a fair hearing. Both legal institutions principally serve public policy and therefore are taken into account by the court on its own initiative. Despite the goal to prevent conflicting judgments and parallel proceedings and to render final judgments stability, certain competing interests invite the legislator to establish exceptions to finality. Balancing the reverse objectives is a policy issue. The legislator can broaden or narrow the scope of res judicata and lis pendens. Under the present rules there is a rather wide opportunity to deteriorate finality with legal recourses available against final judgments. It is true to review appeal that can be grounded on almost any kind of infringement of the law. In the future, it will depend very much on the case law (the interpretation of the leave to appeal conditions) how much this situation will change. Fundamental right considerations will widen the gap in finality as a result of the introduction of a new cause for re-opening. The boundaries of the scope of the res judicata effect is quite blurred, if either the case law or the doctrines are taken. The new Code presumably will bring a considerable reform in this respect by requiring the parties with legal representatives to refer to particular legal provisions as the legal base of the claim and defence, however it cannot be foreseen how far it will be able to eliminate the uncertainty concerning the interpretation of the current rules, especially in relation to preconditions. A new solution will be adopted concerning set-offs, and it will be a clear strengthening of the res judicata effect.

95 Under the current and the previous rules (1911) substantive law excuses do/did not come under the res judicata effect, apart for the single exception as mentioned above (entertained set-off). See the explanation for Sections 410 and 411 of the Act I of 1911 [in: Antalfi (1915) 715].

96 Section 229 (3) of Act III of 1952.

97 Section 360 (1) of the new Code.

98 See more about set-off in civil procedures: Farkas (1976) 75-76. Éless (2016) 257-62. 


\section{LITERATURE}

Antalfi, M., Polgári perrendtartás (Hungarian civil procedural law) (Author's edition, 1915).

Éless, T., and Döme, A., 'Alapvetések a polgári per szerkezetéhez' (The basic doctrines of Hungarian civil court procedure) in Németh, J., and Varga, I. (eds), Egy új polgári perrendtartás alapjai. (HVG-ORAC 2014) 50-78.

Éless, T., and Parlagi, M., 'Az érvényesített joghoz kötöttség' (The principle that the court is bound by the rights claimed by the parties) in Németh, J., and Varga, I., (eds), Egy új polgári perrendtartás alapjai. (HVG-ORAC 2014) 355-61.

Farkas, J., A jogerö a magyar polgári peres eljárásban (The authority of res iudicata in Hungarian civil court procedure) (Akadémiai 1976).

Habermann, G., Jogerő a perenkivüli eljárásban (Res iudicata in non-contentious proceedings) (Szegedi Városi Nyomda és Könyvkiadó Részvénytársaság 1935).

Herczegh, M., Magyar polgári törvénykezési rendtartás (Hungarian civil procedural code) (Franklin 1901).

Kengyel, M., Magyar polgári eljárásjog (Hungarian civil procedural law) (Osiris 2012).

Kovács, M., A polgári perrendtartás magyarázata (Explanatory notes to the Code of Civil Procedure) (Pesti Könyvnyomda 1927).

Kovács, M., A polgári perrendtartás magyarázata (Explanatory notes to the Code of Civil Procedure) ( $2^{\text {nd }}$ edition, Pesti Könyvnyomda 1928).

Magyary, G., and Nizsalovszky, E., Magyar polgári perjog (Hungarian civil procedural law) ( ${ }^{\text {rd }}$ edition, Franklin 1939).

Magyary, G., A magyar polgári peres eljárás alaptanai (A perbeli cselekvények tana) (The basic doctrines of Hungarian civil court procedure) (Franklin 1898).

Pákozdi, Z., A jogerö tárgyi terjedelme a polgári perben (The material scope of res iudicata in civil court procedure) (PhD dissertation, Miskolc 2015).

Pákozdi, Z., 'A pertárgy fogalma jog-összehasonlító megközelítésben' (The notion of subject-matter from a comparative legal approach) in Németh, J., and Varga, I. (eds), Egy új polgári perrendtartás alapjai (HVG-ORAC 2014) 328-54.

Szabó, I., 'A tárgyalás és a határozatok' (Court hearings and decisions) in Osztovits, A. (ed), Polgári eljárásjog I. A polgári per általános szabályai. (HVG-ORAC, Budapest, 2013) 236-337.

Söderlund, C., 'Lis Pendens, Res Judicata and the Issue of Parallel Judicial Proceedings' (2005) 4 Journal of International Arbitration 301-22.

Schönvitzky, B., Az itélet és a jogerő (Judgement and res iudicata) (Szent János Nyomda 1938).

Wopera, Zs., 'A határozatok' (Court decisions) in Cserba, L., Gyekiczky, T., Kormos, E., Nagy, A., and Wopera, Zs., Polgári perjog - Általános rész, (Complex 2008) 419-52. 